\title{
Perceptions of Prospective Science Teachers about Science and Technology Concepts and Scientific-Technological Literacy
}

\author{
Fatma Taşkın Ekici (Corresponding Author) \\ Dept. of Primary Science Teacher Education, Pamukkale University \\ PAU Egitim Fak. Kinikli Kampusu no.132, Denizli, Turkey \\ Tel: 90-258-296-1106. E-mail: fekici@pau.edu.tr \\ Mustafa Aydoğdu \\ Dept. of Primary Science Teacher Education, Gazi University \\ Gazi Universitesi, Gazi Eğitim Fak., Ankara, Turkey \\ Tel: 90-312-202-8196. E-mail: musayd@gazi.edu.tr
}

Received: June 17, 2013 Accepted: September 24, 2013 Published: January 22, 2014

doi:10.5296/ire.v2i1.4965 URL: http://dx.doi.org/10.5296/ire.v2i1.4965

\begin{abstract}
The aim of this study is to determine pre-service science teachers' perceptions about science and technology concepts and to express the thoughts about their scientific and technological literacy. The relational survey method was used about the perceptions of the Junior and Senior degree students of science teacher education program at science and technology concept. The data were collected through on semi structured interview form including 10 items developed by researchers. The research includes 116 pre-service science teachers. The data obtained from participants were analysed qualitatively with using HyperResearch software by open coding technique. The conceptions were interpreted in terms of determined categories and conceptual constructions. According to the findings, the perceptions of the pre-service science teachers on science and technology concepts are generally positive and the perceptions have consistency to the literature. In addition, pre-service teachers show positive behaviour to become literate in science and technology.
\end{abstract}


Keywords: Preserves teacher, science and technology concept, literacy

\section{Introduction}

Recent science education reform efforts have acknowledged its importance by emphasizing the need for students to develop a rich understanding of science, technology, scientific and technology literacy concepts reasoning that such an understanding is necessary to integrate knowledge of the natural world (American Association for the Advancement of Science, 1993; National Research Council, 1995). In today's society, science plays an important role in everyday life where developments are occurring at a rapid pace. Advances in science continue to have a major impact on society and the life of people. It is; therefore, focus has been directed to the overwhelming importance of science education in schools and the advances in science should play a fundamental in growing scientifically literate students.

The primary goal for the current science education reform initiative is to prepare and develop a society that is scientifically literate (AAAS, 1989, 1993; NRC, 1996) who will be responsible for personal decisions that affect the local and global community (Bell, Lederman, \& Abd-El-Khalick, 2000; Smith \& Scharmann, 1999). Not all educators agree to the meaning of the term scientific literacy, and without a clear definition, science reform outcomes are vague, and often difficult to ascertain (DeBoer, 2000) (Cited by Butler, 2009).

The National Science Education Standards (NSES) holds that scientific literacy implies that a person can identify scientific issues underlying national and local decisions and express positions that are scientifically and technologically informed (NSES, 1996). In the National Science Education Standards (1996, p.22), the content standards define scientific literacy.

"Scientific literacy means that a person can ask, find, or determine answers to questions derived from curiosity about everyday experiences. It means that a person has the ability to describe, explain, and predict natural phenomena. Scientific literacy entails being able to read with understanding articles about science in the popular press and to engage in social conversation about the validity of the conclusions. Scientific literacy implies that a person can identify scientific issues underlying national and local decisions and express positions that are scientifically and technologically informed. A literate citizen should be able to evaluate the quality of scientific information on the basis of its source and the methods used to generate it. Scientific literacy also implies the capacity to pose and evaluate arguments based on evidence and to apply conclusions from such arguments appropriately" (NSES, 1996, p. 22).

Definitions related to scientific literacy started to appear in literature since 1950s and this concept attracted the attention of many scientists since then. Many definitions have been put forward for scientific literacy since Paul deHard Hurd used the term in 1958 (American Association for the Advancement of Science [AAAS], 1989; Bybee, 1997; Gräber et al., 2001; Holbrook \& Rannikmae, 1997; Hurd, 1958; Laugksch, 2000; National Science Education Standards [NSES], 1996; Organisation for Economic Cooperation and Development [OECD], 2003 ; 2007). As a result, owing to the fact that scientists studied with different dimensions of 
scientific literacy in the literature, they put forward several different descriptions of the scientific literacy-from each other.

\subsection{Literature Review}

Norris and Philips (2003) contend that the term scientific literacy has been used to include various components from the following: "Knowledge of the substantive content of science and the ability to distinguish from non-science; Understanding science and its applications; Knowledge of what is considered as science; Independence in learning science; Ability to think scientifically; Ability to use scientific knowledge in problem solving; Knowledge needed for intelligent participation in science-based issues; Understanding the nature of science, including its relationship with culture; Appreciation of and comfort with science, including its wonder and curiosity; Knowledge of the risks and benefits of science; and Ability to think critically about science and to deal with scientific expertise".

Scientific literacy has been represented differently by science educators and researchers according to their individual perspectives and so remained an elusive concept (Bybee, 1997; Hurd, 1998). Scientific literacy has been associated with scientific content knowledge, ways of thinking, and understandings of scientific facts, concepts and processes (Rascoe, Chun, Kemp, Jackson, Li, Oliver, \& Tippins, 1999) or as part of an individual's intellectual ability or accomplishments in building socially informed, competent and responsible citizenship in a democratic society (Bybee,1997). An understanding of the meaning of scientific literacy is fundamental for improving the quality of science teaching and learning and for developing scientifically literate citizens.

Nowadays, people have turned to online resources to get news and information, to shop, make travel reservations, socialize with friends who live both far and near, watch their favorite television shows and movies, and play games with people who live far from their communities and whom they may have never met in person. This assertion acknowledges the fact that an understanding of science and technology through school science is essential for students in order to understand and cope with the demands of the modern world. According to Goodrum et al. (2001), school curriculum often separates science from technology and so students find science not interesting and not related to their lives. Layton, Jenkins and Donnelly (1994) argue that science and technology are relevant to scientific literacy and as such, should be secluded. Jenkins (1992) further notes that science teaching do not need to concentrate on scientific features, laws and principles but to be taught within the context of technology.

Science and technology issues; therefore, need to involve teaching science concepts through technology so that science is developed through interesting contexts (Osborne \& Collins, 2000; Shamos, 1995). Also Science, Technology and Society issues should be included in the school science curriculum so that learners can develop scientific and technological literacy (Bybee, 1997). These points suggest to integration of technology to educational system for developing scientifically and technologically literate citizens. Science, technology and society issues should involve science and technology concerns so that citizens can develop scientific and technological literacy to live as good and responsible citizens and for them to 
cope with contemporary scientific and technological advancement.

Science and technology confront individuals at personal, community, national and even global levels. Hence, it is important for policy-makers to ask about the degree to which all individuals in society are prepared to in relevant content areas and have understanding of them (OECD, 2006).

The International Society for Technology in Education has developed the National Educational Technology Standards for Students (NETS) (ISTE, 2007), which outlines critical skills that students should develop to be prepared for the future. These standards describe "What students should know and be able to do to learn effectively and live productively in an increasingly digital world," (p. 1) which includes skills and dispositions such as: (a) creativity and innovation, (b) communication and collaboration, (c) research and information fluency, (d) critical thinking, problem solving, and decision making; (e) digital citizenship, and (f) technology operations and concepts (ISTE, 2007).

According to the National Science Education Standards (1996), "the goal of science is to understand the natural world, and the goal of technology is to make modifications in the world to meet human needs" (p. 24). Nevertheless, the close relationship between science and technology is acknowledged as: A single problem often has both scientific and technological aspects. The need to answer questions in the natural world drives the development of technological products; moreover, technological needs can drive scientific research. And technological products, from pencils to computers, provide tools that promote the understanding of natural phenomena (p. 24)

Technological literacy has been defined in various ways. In 2000, the International Technology Education Association (ITEA) stated that technological literacy is "the ability to use, manage, assess, and understand technology" (p. 9). This definition was put forth-in Standards for Technological Literacy to challenge educators, specifically those in the field of technology education, to redirect their curriculum to focus on students becoming technologically literate.

When the students understand the relationship between science and technology, they comprehend how to affect each other and how these develop in social context and how to be used for improving peoples' living conditions.

\section{Research Design}

This study examines Turkish pre-service elementary science teachers' perceptions related to science, technology and scientific and technological literacy concepts. The research has taken place in Gazi University, in 2007-2008 Academic years. The research participants were 116 volunteer students chosen among all senior classes of the university mentioned above. The research data were gathered with the document containing 10 items. What do you understand by science? Is the science necessary for technology? What do you understand by technology?

Patton (1990) and Thomas and Nelson (1996) also corroborate that using the focus group meetings and interviews can help researchers to gather information on several people's views, 
perceptions and opinions in one session and for the participants to provide checks and balances on each other's views, which can curb extreme views. Thus, qualitative methods is necessary for generalizing plausible alternative explanations, describing the program, constructing a narrative history, presenting data collection procedures, and summarizing (Campbell, 1974) and to help allow the researcher to have more continuous reflection on the research in progress, more interaction with the participants in the research, and more room for ongoing alteration as the research proceeds (Bouma, 2000).

Data of the research have been gathered by Science and Technology View Questionnaire which includes 10 open-ended questions supported by some interviews. When the questionnaire has been constructed, it has been used the literature and student teachers' pre-interview questions. It has been included 116 primary science teachers in this research. The data gathered from participant student teachers has grouped by open coding and analyzed by the HyperResearch 2.0 Qualitative Data Analysis Software.

\section{Results and Discussion}

Before considering the pre-service teachers' responses to question, a brief attempt is made to contextualize each question. The qualitative responses were categorized and appropriate labels were attributed by the authors according to key phrases mentioned by the pre-service teachers. Quotations attributed informally are those of the students. All responses in the tables are expressed and quantified as percentages and frequency. These findings are presented below as they relate to the guiding questions.

\subsection{The Meaning of Science}

The question of "What is the science?" has been a question which scientists couldn't be made a common decision in definition and couldn't be provided a consensus to response for years. Questions that fail to reach a common decision on the definition of the science depend on a continuously developing and advancing fact of it and it has unclear boundaries in terms of its issues and methods, it is sophisticated. Indeed, it is very difficult to state a definition as everyone can accept because of its unclear boundaries, sophisticated process.

Table 1. The Question of "What do you understand by science?"

\begin{tabular}{lll}
\hline Science is: & $\%$ & $\mathrm{f}$ \\
\hline Production of Knowledge. Everything discovered or product. & $\% 11$ & 13 \\
A systematic structure. & $\% 26$ & 30 \\
Explaining and sense of the life. & $\% 15$ & 17 \\
Positive responses of the philosophy. & $\% 1$ & 1 \\
Based to Theories and wide-ranging set of information. & $\% 31$ & 35 \\
Examines the universe and events in the universe. & $\% 16$ & 18 \\
Empty. & $\% 1$ & 2 \\
\hline
\end{tabular}

All of the interviewed student teachers stated that science could be evidenced by observations and experiments, it is a theoretical system and it is needed to retrace specific procedures to 
attain science. Some statements of the student teachers as below:

- Science is production of knowledge and information. Besides of this, it is using of the information accurately.

- Science is a comprehensive and advanced field to attain new information, to obtain new products and to present them to technology.

Bloom (1989), has asked the question of "What is science?" to 80 primary prospective teachers in order to determine their views about the concept of science and has grouped the responses under the specific categories. Responses given from prospective students in the Bloom's study were; "science: is mechanism of the earth and universe, is discovery, are researches, is to research the explanations, is to understand the explanation, is to understand the events in daily life, is to discover and to reveal, is method, is procedure, is experiment and observation. Bloom divided these responses into four categories. First category was mechanism of the earth which included concepts of universe and its mechanism, second category was included concepts which stated science as method and procedure and he associated these concepts with research methods and experiences. The third category contains how they explained something that we encountered in daily life and it contains the proofs which reinforces to the explanations. The last category summed up the concepts of advancements in technology and medicine under the title of research for new developments.

Abell and Smith (1994), done a study same with the Bloom's study, they have also asked the question of "What is Science?" to learn the prospective science teachers' opinions about the science. In this research, $\% 25$ of the prospective teachers stated that science is a method or procedure. They also associated with the other categories, while they state the science is a method. \% 13,5 of the participants did a definition containing both two categories. The other responses were the reals, verifies, replies, products, doctrines. Abell and Smith summed up these concepts under the title of Amount of Information. These researchers have constituted five categories from the responses of the participants. Education category from these categories has not taken place in Bloom's categories. In the study of Abell and Smith, they have done such classify the cause of $\% 20$ of the participants defined the science as science education.

In the study done by Murcia and Schibeci (1999), $\% 63$ of 73 prospective teachers defined the science as mechanism of the earth, $\% 21$ of them as method, $\% 17$ of them as account of information, $\% 1$ of them as research for new development. $\% 13$ of them was irresponsive this question.

Table 2. The Question of "What do you mean that science is produced in science?"

\begin{tabular}{lll}
\hline Science is produced in science about: & $\%$ & $\mathrm{f}$ \\
\hline Disciplines of Science & $\% 9$ & 11 \\
Natural Events & $\% 24$ & 29 \\
Making Concrete of Technology and Knowledge & $\% 40$ & 48 \\
Social Events & $\% 27$ & 35 \\
\hline
\end{tabular}


$\% 9$ of the responded participants has stated that they are disciplines of science (e.g. Physics, Biology, etc.) to the question of "What do you mean that science is produced in science?" The student teachers stated that the scientific products are disciplines that have been derived from scientific researches depended on their research focuses.

$\% 24$ of them stated as natural events. These student teachers stated that scientific products are all the events occurred on the earth depends on a cause, natural events and knowledge disclosed by experiments and observations, information helps to recognize ourselves, environment and nature.

- "Product of science is produced in science" means that every event occurred on the earth is also an apple falling down a tree is not coincident, and relies on a cause.

- It helps to solve some problems in our life and to understand that is complex structure. It can be a mediator in solving the problems such as in medicine. It can be effective in present to us a more comfortable and livable life such as cars and the other advantages same with that.

These findings consist with the studies from the literature. Martin (1997), stated that the products of science are materials, phenomenon, concepts, theories, ideas and attitudes which have scientific content exhibited as results of scientific study and divided into three categories.

(1) Materials (Matters): Computers, mobile phones, jet planes

(2) Theory and Ideas: Phenomenon, concepts, theories, laws

(3) Attitudes

In this study, opinions of the participants have been divided into groups such "Science Disciplines", "Natural Events", "Making Concrete of Technology and Knowledge" and "Social Events". When these groups are arranged under the three main titles, they can overlap with the classifying of Martin. For example, making concrete of technology and knowledge can be thought under the materials and theories and ideas titles, because, some statements such as materials which facilitate to life and conceptualization and concrete of events which had difficulty in understanding have been investigated in same group. Martin's classification has no science disciplines title, however, this title can be thought under the theories and ideas title of Martin.

When asked to the student teachers the question of "How is the product of science used in society?" and 94 of them responded to the question and responses have grouped as below. 
Table 3. The Question of "How is being used the product of science in society?"

\begin{tabular}{lll}
\hline How is the product of science used in society? & $\%$ & $\mathrm{f}$ \\
\hline Facilitate to daily life & $\% 47$ & 43 \\
Medicine for Health & $\% 18$ & 17 \\
Defense in Military & $\% 4$ & 4 \\
Education & $\% 6$ & 6 \\
Communication & $\% 3$ & 3 \\
Industry & $\% 7$ & 7 \\
Multiple Fields & $\% 9$ & 8 \\
Specific Use to Science Disciplines & $\% 6$ & 6 \\
\hline
\end{tabular}

Many of the prospective teachers stated that products of science are used to facilitate to daily life and expressed their opinions in terms of meeting the basic needs and making their lifestyle more comfortable in the nature. The some other prospective teachers stated that many product of science have been used by peoples as indispensable tools even if they aren't aware of that. Some statements of prospective science teachers were the followings:

- It is on the top level of our daily life. For example, lenses shades off to glasses; the electric circuits illuminate our life; food information can save our life.

- In medicine, peoples use several technological products to acquire comfortable life standards (e.g., mobile phones). These products raise their life standards, at the same time, they damage their health. For this reason, medicine has to be a step front of the technological advances and it has to make precautions.

When asked the question of "What is technology?" to the prospective science teachers, $\% 22$ of the pre-service teachers that answered the question stated as application of science. These participants' statements are such as "technology is using form of the science in daily life", "application of science to facilitate daily life" etc.

Table 4. The Question of "What is Technology?"

\begin{tabular}{lll}
\hline Technology is & $\%$ & $\mathrm{f}$ \\
\hline Application of Science & $\% 22$ & 22 \\
Scientific Development & $\% 10$ & 10 \\
Invention & $\% 26$ & 26 \\
Process & $\% 3$ & 3 \\
Product & $\% 39$ & 39 \\
\hline
\end{tabular}

Some participant statements related to the question are as below.

- Making science more useful, applying to daily life.

- It is a discipline that builds bridge between science and application. It includes 
not only knowing the equipment, but also how to be used and where they are utilized.

The statements of the student teachers who stated that technology is inventions are as below.

- Devices and equipment which are devised by scientific advamcements constitute the technology.

- They are equipment which is produced and devised to become available of science in daily life.

The statements of the student teachers who stated that technology is product of the science are as below.

- Technology depending on scientific developments is products which are constituted for peoples' needs and which usually have facilitative effect on life.

- They are different products which will facilitate to life of individuals or which are made for a different purpose.

The question of "Is the science essential for technology?" was asked to the participants, the majority of them (\%88 of respondents) stated positive responses while $\% 4$ of them stated negative responses. 4 student teachers maintained that technology can exist even if it is without science. 8 participants have maintained that the technology and the science completed each other.

Table 5. The Question of "Is the science essential for technology?"

\begin{tabular}{lll}
\hline Is the science essential for the technology? & $\%$ & $\mathrm{f}$ \\
\hline Yes & $\% 88$ & 88 \\
No & $\% 4$ & 4 \\
The same level & $\% 8$ & 8 \\
\hline
\end{tabular}

When it has been asked to participants the question of "What is the mean of scientific literacy?" the responses of the respondents grouped as the table below (Table 6)

Table 6. The Question of "What is the mean of scientific literacy?"

\begin{tabular}{lll}
\hline What is scientific literacy & $\%$ & $\mathrm{f}$ \\
\hline Scientist & $\% 3$ & 3 \\
To Understand the Science and Using Them in Daily Life & $\% 21$ & 21 \\
Knowing Scientific Advancements & $\% 20$ & 20 \\
The Criterion of Scientific Literacy & $\% 13$ & 13 \\
To Follow Journals, Newspapers and Other Publications & $\% 40$ & 40 \\
Common Language Used by Scientists & $\% 3$ & 3 \\
\hline
\end{tabular}




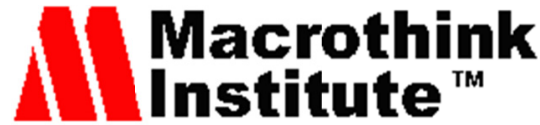

The most explicit and most frequently used statements are "to understand the science" and "to be informed" and "to use in life" in the statements of the prospective teachers who stated that the scientific literacy is understanding of science and commenting in daily life. Some statements of them are as below.

- To exhibit the personal ideas about the science or to offer solutions for the deficiencies exhibited in the process of advancement of the science or to transfer cause-effect and to use peoples'purposes on the science.

- To be able to learn knowledge based science and to form in our life.

- To realize and to understand scientific phenomenon in our environments and to be aware of them while using.

Some statements of the Prospective Teachers who stated that scientific literacy is to follow the publications such as journals and newspapers is as below

- Interest, read and write everything which has scientific qualification.

- Read and write publications and books related to science. Be interested in scientific topics.

- To follow revealed scientific knowledge from daily publications.

These findings is consistent with the literature (above, in the Table 6). It hasn't been provided a consensus about the definition of the scientific literacy and we can see some different definitions from different scientists and researchers. Therefore, it has not been evaluated participants' responses as true or false.

The concept of scientific literacy has been defined first by Hurd. As stated by Hurd (1958), scientific literacy is, to help to grow capable and responsible peoples in society, to develop logical thinking skills about societal, political and economic issues and problems which they can come across related to science and to understand the science concepts. This definition of Hurd is consistent with the statements in the category of "to understand the science and use in daily life".

It has also been asked the question of "What is the meaning of technological literacy?" The responses grouped under the titles as table below (Table 7). 100 prospective teachers have responded the question.

Table 7. The Question of "What is the meaning of technological literacy?"

\begin{tabular}{lll}
\hline What is the meaning of technological literacy? & $\%$ & $\mathrm{f}$ \\
\hline To be informed from technological advancements and to can use the products & $\% 64$ & 64 \\
\hline To produce new products & $\% 3$ & 3 \\
\hline To apply technology to the life & $\% 11$ & 11 \\
\hline To can use the technology & $\% 10$ & 10 \\
\hline To read journal, newspaper or book related to technology & $\% 12$ & 12 \\
\hline
\end{tabular}




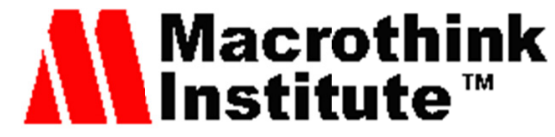

The most of the responses were grouped under the title of "To be informed from technological advancements and to be able to use the products". The statements related to technological literacy have been coded in five categories. But some statements have been repeated under the other coding. The statements of "using technological products" have taken place in the same category with the following "technological advancements". However, "the using technology in daily life" has also been represented as a separately category because of interviews with participants. While a group of participants found it adequate to use technological products for technology literacy, a group of them didn't find enough. Because of this, two separate coding has been done for these responses.

Some statements of the respondents are as below.

- Technological literacy is to be informed by technological advancements, to use technological products and not to be far from them.

- To follow several media related to them and to be informed by technological advancements.

From the statements, technology literacy is defined as to use, to direct, to evaluate and to understand the technology as a summary. A technological literate person will understand what is technology, how it is created, how it is formed the society and its importance given to use in society with several given ways (e.g. with reading several sources and with interest and wonder) over time.

After the these questions (related to definition of scientific and technology literacy), it has been asked to participants the question of "How literate of science and technology are you?". They stated that their literacy was graded as good, middle and bad (not enough) with their statements as table below (Table 8). Besides of this grading, some of the participants stated that they were literate of science but not of technology, while the others stated that they were literate of technology but not of science.

Table 8. The Question of "How much you are scientifically and technologically literate?"

\begin{tabular}{lll}
\hline How much you are scientifically and technologically literate? & $\%$ & $\mathrm{f}$ \\
\hline Good & $\% 12$ & 12 \\
Middle & $\% 58$ & 58 \\
Bad & $\% 19$ & 19 \\
I have Scientific literacy & $\% 3$ & 3 \\
I have Technology literacy & $\% 8$ & 8 \\
\hline
\end{tabular}

Some statements of 58 participants of the total respondents stated that they accepted themselves in middle degree for scientific and technology literacy as below. 
Although I'm not a science and technology literate completely, I enjoy reading the writings which comment on physical, chemical and biological events in my environment. But I don't give rein myself. For this reason, I can say it is in middle level.

- I have some specific knowledge and background on the some part of the science and technology for I have been seeing and repeating for years. But a literate of them would never consider him (her) self adequate. For this reason, I'm not quite adequate. In middle level...

It has been asked them the criteria of the scientific and technological literacy and the 94 prospective science teachers responded this question. The responses grouped as the table below (Table 9.)

Table 9. The Question of "What are the criteria of science and technology literacy?"

\begin{tabular}{|c|c|c|}
\hline What are the criteria of science and technology literacy? & $\%$ & \\
\hline $\begin{array}{l}\text { To be informed the advancements in the scientific and technological fields and to use and to } \\
\text { interpret them }\end{array}$ & $\% 40$ & 37 \\
\hline Reading of sources (journals, newspapers, books or articles) related to science and technology & $\% 33$ & 31 \\
\hline The Level of Education & $\% 17$ & 16 \\
\hline Using of Technology consciously & $\% 7$ & 7 \\
\hline To participate to fairs or exhibitions related to science and technology & $\% 3$ & 3 \\
\hline
\end{tabular}

Some of the statements of the prospective science teachers whose responses coded as "To be informed the advancements in the scientific and technological fields and to use and to interpret them" are as below.

- Criteria of the scientific and technological literacy, in my opinion, is to be informed about advancements in the field of science and technology and to be able to be utilized from them

- The peoples' applying technology to daily life and using the products of technology can be useful as criteria.

According to these findings, it can be thought that there are some criteria for literate of science and technology and the prospective teachers are aware of them. With these findings, we can propound that the literate of science and technology is recognized by reading journal, newspaper or book, to research interesting topics, the level of education and to behave consciously while using products.

In real, with given technology education to individuals, it is provided to be literate of technology of persons. The International Technology Education Association (ITEA) and its Technology for All Americans Project developed "The Standards for Technological Literacy: Content For the Study of Technology" and in these standards designated the person who is literate of technology needs to do and to know the technology. These are summarized as below: 
A person that understands, with increasing sophistication, what technology is, how it is created, how it shapes society, and in turn is shaped by society is technologically literate. He or she can hear a story about technology on television or read it in the newspaper and evaluate its information intelligently, put that information in context, and form an opinion based on it. A technologically literate person is comfortable with and objective about the use of technology - neither scared of it nor infatuated with it.

Technological literacy is important for all students in order for them to understand why technology and its use is such an important force in our economy. Anyone can benefit by being familiar with it. Everyone from corporate executives to teachers to farmers to homemakers will be able to perform their jobs better if they are technologically literate. Technological literacy benefits students who will choose technological careers; e.g. future engineers, aspiring architects, and students from many other fields. They can have a head start on their future with an education in technology (ITEA, 2000).

Finally, the question of "What are the technologies do you use in daily life?" has been asked and it has also been called upon to sort from the most indispensable of them to the others. This question has been responded by all participants and they sorted then as the computers, mobile phones, MP3 Players, Flash Memory, TVs, Clocks, Cameras, Photocopy Machines, Electrical Appliances and Transportation Vehicles.

- Mobile phone, computer, cameras, washing machine, TV, briefly electrical appliances used at home

- Mobile phone, computer, car, tram, TV, music set, natural gas system, electrical energy

- Computer, phone, television, radio... technological devices the most used by me and the washing machine, fridge, dishwasher are other examples of it.

\section{Conclusion}

In summary, the pre-service science teachers examined several aspects of concepts of both science and technology and meaning of scientific and technological literacy; technical, societal, cultural and ethical. They provide practical application and understanding of scientific and technological knowledge in science and technology learning with focus on their relevance in daily life in practical contexts as an explanation of the semantic, cultural and social dimensions of science and technology as a human endeavor.

However; the pre-service teachers have different definition of the terms of science and technology. Documents displayed that although participants had some traditional understandings about science except for a few participants, they hold more contemporary and current views about scientific literacy.

Individuals displayed their scientific literacy in different ways, such as frequently using of technical terms or applying scientific concepts and processes. And pre-service teachers often have different literacy in different domains, such as while they have more understanding concepts and words related to daily life, they have less understanding of technical concepts 
and words of science and technology.

\section{References}

AAAS (American Association for the Advancement of Sciences). (1989). Science for all Americans: A Project 2061 report on literacy goals in science, mathematics and technology. Washington DC: Author.

AAAS (American Association for the Advancement of Sciences). (1993). Benchmarks for science literacy. New York: Oxford University Press.

Abell, S. K., \& Smith, D. C. (1994). What is science? Preservice elementary teachers' conceptions of the nature of science. International Journal of Science Education, 16(4), 475-487. http://dx.doi.org/10.1080/0950069940160407

Bell, R. L., Lederman, N. G., \& Abd-El-Khalick, F. (2000). Developing and acting upon one's conception of the nature of science: A follow-up study. Journal of Research in Science Teaching, 37 , 563-581. http://dx.doi.org/10.1002/1098-2736(200008)37:6<563::AID-TEA4>3.0.CO;2-N

Bloom, J. W. (1989). Preservice elementary teachers' conceptions of science: Science, theories and evolution. International Journal of Science Education, 11(4), 401-415. http://dx.doi.org/10.1080/0950069890110405

Bouma, G. D. (2000). The research process. Oxford, New York: Oxford University Press.

Butler, W. (2008). Does The Nature Of Science Influence College Students' Learning Of Biological Evolution?. Electronic Theses, Treatises and Dissertations, Paper 2415 (Florida State University, College of Education, PhD Dissertation)

Bybee, R. W. (1997). Achieving scientific literacy: From purposes to practices. Portsmouth, NH: Heinemann.

Cajas, F. (2001). The science/technology interaction: Implications for science literacy. Journal of Research in Science Teaching, 38(7), 715-729. http://dx.doi.org/10.1002/tea.1028

Campbell, D. T. (1974). Qualitative knowing in action research. Paper presented at the annual meeting of the American Psychological Association. New Orleans, USA

DeBoer, G. E. (2000). Scientific literacy: Another look at its historical and contemporary meanings and its relationship to science education reform. Journal of Research in Science Teaching, 37 , 582-601. http://dx.doi.org/10.1002/1098-2736(200008)37:6<582::AID-TEA5>3.0.CO;2-L

Goodrum, D., Hackling, M., \& Rennie, L. (2001). The status and quality of teaching and learning of science in Australian schools: A research report. Canberra: Department of Education, Training and Youth Affairs. 
Gräber, W., Erdmann, T., \& Schlieker, V. (2001). ParCIS: Partnership between Chemical Industry and Schools. Retrieved November 2008, from http://www.ipn.uni-kiel.de/_chik_symposium/sites/pdf/graeber.pdf

Holbrook, J., \& Rannikmae, M. (2007). Nature of science education for enhancing scientific literacy. International Journal of Science Education, 29(11), 1347-1362. http://dx.doi.org/10.1080/09500690601007549

Hurd, P. D. (1998). Scientific literacy: New minds for a changing world. Science Education, 82 , 27-30. http://dx.doi.org/10.1002/(SICI)1098-237X(199806)82:3<407::AID-SCE6>3.0.CO;2-G

Hurd, P. D. (1958). Science literacy: Its meaning for American schools. Educational Leadership, 16(1), 13-16.

ISTE (International Society for Technology in Education). (1998). National educational technology standards for students. Eugene, OR: Author.

ITEA (International Technology Education Association, Technology for All Americans Project). (2000). Standards for technological literacy: Content for the study of technology. Reston, VA: Author.

ITEA (International Technology Education Association, Technology for All Americans Project). (1996). Technology for all Americans: A rationale and structure for the study of technology. Reston, VA: Author.

Krupczak, Jr. J., \& Ollis, D. F. (2005, April). Improving the technological literacy of undergraduates: Identifying the research issues. Workshop sponsored by The National Science Foundation. National Academy of Engineering, Washington, DC.

Laugksch R. C. (2000). Scientific Literacy: A conceptual overview. Science Education, 84, 71-94. http://dx.doi.org/10.1002/(SICI)1098-237X(200001)84:1<71::AID-SCE6>3.0.CO;2-C

Layton, D., Jenkins, E., \& Donnelly, J. (1994). Science and technological literacy: Meanings and rationales. Leeds, UK: University of Leeds, Center for Studies in Science and Mathematics Education, in association with UNESCO.

Martin, B. (1997). Science, technology and nonviolent action: the case for a utopian dimension in the social analysis of science and technology. Social Studies of Science, 27, 439-463. http://dx.doi.org/10.1177/030631297027003003

Massachusetts Department of Education. (2001). Science and technology/engineering curriculum framework. Retrieved July 10, 2007, from http://www.doe.mass.edu/frameworks/scitech/2001/standards/strand4.html

Millar, R. (2006). Twenty first century science: Insights from the design and implementation of a scientific literacy approach in school science. International Journal of Science Education, 28(13), 1499-1521. http://dx.doi.org/10.1080/09500690600718344 


\section{Macrothink}

International Research in Education

ISSN 2327-5499

2014, Vol. 2, No. 1

Millar, R., \& Osborne, J. (1998). Beyond 2000. Science education for the future. London: Nuffield Foundation.

Miller, J. (2006). Civic scientific literacy in Europe and the United States. Paper presented at the Annual Meeting of the World Association for Public Opinio Research, Montreal, Canada.

Miller, J. D. (1989). Scientific literacy. Paper presented at the American Association for the Advancement of Science annual meeting, San Francisco, CA.

NAE \& NRC (National Academy of Engineering \& National Research Council). (2006). Tech Tally: Approaches to assessing technological literacy. Washington, DC: National Academies Press.

NAE \& NRC (National Academy of Engineering \& National Research Council). (2002). Technically speaking: Why all Americans need to know more about technology. Washington, DC: National Academy Press.

National Science Education Standards. (1996). National Academy of Sciences. Washington DC: National Academy Press.

Norris, S. P., \& Phillips, L. M. (2003). How literacy in its fundamental sense is central to scientific literacy. Science Education, 87, 224-240. http://dx.doi.org/10.1002/sce.10066

NRC (National Research Council). (1996). National science education standards. Washington, DC: National Academy Press.

NSTA. (1992). The use of computers in science education. Retrieved June 24, 2003, from http://www.nsta.org/handbook/computer.asp National research council (NRC). National academy of sciences Washington, d.c. 1995

Osborne, J., \& Collins, S. (2000). Pupils'and parents' views of the school science curriculum. London: King's College London.

Patton, M. Q. (1990). Qualitative evaluation and research methods. Newbury Park: Sage Publications.

Rascoe, B., Chun, S., Kemp, A., Jackson, D. F., Li, H., Oliver, J. S., ... Radcliffe, L. (1999). Scientific literacy: Interpretations of cross-section of our society. Paper presented at the Annual meeting of the National Association for Research in Science Teaching, Boston, MA. Retrived June 21, 2003, from http://www.educ.sfu.ca/narstsite/conference/rascoeetal/rascoeetal.html

Shamos, M. H. (1995). The myth of scientific literacy. New Brunswick, NJ: Rutgers University Press.

Smith, M. U., \& Scharmann, L. C. (1999). Defining versus describing the nature of science: A pragmatic analysis for classroom teachers and science educators. Science Education, 83, 493-509.

http://dx.doi.org/10.1002/(SICI)1098-237X(199907)83:4<493::AID-SCE6>3.0.CO;2-U 


\section{Macrothink}

International Research in Education

ISSN 2327-5499 2014, Vol. 2, No. 1

Thomas, J. R., \& Nelson, J. K. (1996). Research methods in physical activity. Champaign, IL: Human Kinetics.

\section{Copyright Disclaimer}

Copyright reserved by the authors.

This article is an open-access article distributed under the terms and conditions of the Creative Commons Attribution license (http://creativecommons.org/licenses/by/3.0/). 